\title{
What kind of rationalization is system justification?
}

\author{
Kristin Laurin \& William M. Jettinghoff \\ University of British Columbia
}

This is an unedited commentary submitted to Behavioral and Brain Sciences.

Target Article: Cushman, F. (n.d.). Rationalization is rational. Behavioral and Brain Sciences, 1 - 69. doi:10.1017/S0140525X19001730

Corresponding author: Kristin Laurin, klaurin@psych.ubc.ca

University of British Columbia

Department of psychology

2136 West Mall

Vancouver, BC

V6T $1 Z 4$

CANADA 


\begin{abstract}
Cushman uses rationalization to refer to people's explanations for their own actions. In system justification theory, scholars use the same term to refer to people's efforts to cast their current status quo in an exaggeratedly positive light. We try to reconcile these two meanings, positing that system justification could result from people trying to explain their own failure to take action to combat inequality. We highlight two novel and contested predictions emerging from this interpretation.
\end{abstract}




\section{Commentary}

In this target article, Cushman uses rationalization to mean something different than we initially expected. He uses it to refer people explain their behavior: When one "takes an action that has already been performed and then concocts the beliefs or desires that would have made it rational." In the system justification tradition, rationalization refers quite differently to people reinterpreting seemingly negative features of their sociopolitical systems, "adjusting their preferences to fit with their expectations about what is likely to occur" [1, p. 889]; see also [2, 3].

How can rationalization mean both explaining one's own behavior (per Cushman), and trying to feel better about the world one lives in (per system justification)? It could be a coincidence: Some words simply have multiple meanings. Here, we focus on two more fruitful possibilities.

\section{Is system justification an instance of theory of mind plus social learning?}

One is that system justification comes from our tendency to infer (through theory of mind), and then adopt (through social learning), others' mental states. Cushman points out that this two-process sequence is exactly parallel to his meaning of rationalization: In each case, we observe (our own vs. another's) behavior, then infer and adopt the beliefs or desires that would have made it rational. System justification could be an instantiation of that two-process sequence: Justifying, for instance, gender pay gaps might be a by-product of trying to infer the rationale by which individual employers pay women less than men.

This account is plausible, but does not explain why the extracted rationales so frequently tend to justify the system. System justification's main tenet would require that people be especially likely to infer in employers, and then adopt for themselves, beliefs and desires that justify the system, or paint it in a positive light. For example, they should be especially drawn to extract the rationale that women must be less deserving of good pay. But if people were merely 
trying to identify beliefs and desires that would lead employers to rationally pay women less, there would be no reason to expect system justifying rationales to predominate. Rationales that are neutral or even blame the system should be just as likely: For example, people could infer that women's are less likely to retaliate than men in response to a mediocre offer. Thus, to account for the primacy of system justifying beliefs, the theory of mind plus social learning account requires additional assumptions that are not immediately obvious. We therefore explore an alternative that does not require such additional assumptions, and also generates novel and contested predictions.

\section{Is system justification the rationalization of one's own complacency?}

This alternative is that people's tendency to rationalize undesirable features of society comes from their attempt to extract rationales that explains their own tacit support for it. In this account, people are not trying to explain the gender pay gap itself, but rather their own failure to fight it. This would account for the special appeal of system justifying beliefs, particularly among the politically complacent (i.e., most humans [4]): By definition, system justifying beliefs portray the status quo as more desirable, making action seem less necessary and complacency more rational.

Though consistent with the cognitive dissonance roots of system justification [5], this interpretation departs from most recent literature, which tends to imply that people are motivated to justify the system itself: They resolve dissonance between their preferences and a nonpreferred reality with the ultimate goal of feeling good about the status quo [6, 7]. Instead, this new interpretation suggests people may be rationalizing their own tacit support for the system: They resolve dissonance between their inaction (and its implication that they prefer the status quo) and a non-preferred reality, striving to see themselves as rational actors. This leads to at 
least two novel predictions conflicting with assumptions in the current system justification literature.

When will people stop justifying the system? Mainstream system justification literature predicts that people will only stop rationalizing the system when they believe it may change [810]. For example, if people expect gender inequality to shrink, then they should have no need to justify it, because their preferences and reality will soon be consonant.

By contrast, our Cushman-inspired re-interpretation of system justification predicts that people will stop rationalizing the status quo when they have attempted, even unsuccessfully, to change it, because the non-preferred reality is now consonant with their actions. For example, attending a feminist protest, even without any expectation that it would accomplish anything, should relieve any need to justify gender inequality, because one's actions are now in line with preferring gender parity.

Can complacency be explained without system justification? For another, our interpretation suggests a new alternative to system justification altogether: Rather than explaining their complacency by portraying action as unnecessary (i.e., by justifying the system), people might portray action as unfeasible. Accordingly, if we highlight the non-trivial costs of taking action against the system, that should release people from their tendency to justify the it: If the costs of attending a gender equality protest (e.g., money lost in hourly wages, effort spent constructing a sloganized poster, etc.) explains why you have not attended a single one, then you no longer need to extract a belief that justifies gender inequality to explain your inaction. This prediction runs counter to what mainstream system justification research predicts: If anything, from that view, highlighting the costs of action should make the system seem even more static, which should in turn encourage people to justify it, rather than the opposite (e.g., [2]).

\section{Conclusion}


Applying Cushman's target article to system justification's version of rationalization leads to a new and parsimonious interpretation of system justification that generates two sets of contrasting predictions. Future research might test the following questions: (1) Will people only stop rationalizing when they believe attempts to change the status quo will succeed, or is merely participating in even an unsuccessful attempt sufficient?, and (2) Does highlighting the costs of attempting to change the system increase or decrease people's tendency to justify it? 


\section{References}

[1] Jost, J. T., Banaji, M. R., \& Nosek, B. A. (2004). A decade of system justification theory: Accumulated evidence of conscious and unconscious bolstering of the status quo. Political psychology, 25(6), 881-919.

[2] Laurin, K., Gaucher, D., \& Kay, A. (2013). Stability and the justification of social inequality. European Journal of Social Psychology, 43(4), 246-254.

[3] Laurin, K., Kay, A. C., Proudfoot, D., \& Fitzsimons, G. J. (2013). Response to restrictive policies: Reconciling system justification and psychological reactance. Organizational Behavior and Human Decision Processes, 122(2), 152-162.

[4] "Many Around the World Are Disengaged From Politics" Pew Research Center, Washington, D.C. (October 2018). https://www.pewresearch.org/global/2018/10/17/internationalpolitical-engagement/

[5] Jost, J. T., \& Banaji, M. R. (1994). The role of stereotyping in system-justification and the production of false consciousness. British journal of social psychology, 33(1), 1-27.

[6] Bahamondes, J., Sibley, C. G., \& Osborne, D. (2019). "We look (and feel) better thrugh system-justifying lenses": System-justifying beliefs attenuate the well-being gap between the advantaged and disadvantaged by reducing perceptions of discrimination. Personality and Social Psychology Bulletin, 45(9), 1391-1408.

[7] Suppes, A., Napier, J. L., van der Toorn, J. (2019). The palliative effects of system justification on the health and happiness of lesbian, gay, bisexual, and transgender individuals. Personality and Social Psychology Bulletin, 45(3), 372-388.

[8] Kay, A. C., Jimenez, M. C., \& Jost, J. T. (2002). Sour grapes, sweet lemons, and the anticipatory rationalization of the status quo. Personality and Social Psychology Bulletin, 28(9), 1300-1312. 
[9] Laurin, K. (2018). Inaugurating rationalization: Three field studies find increased rationalization when anticipated realities become current. Psychological science, 29(4), 483-495.

[10] Laurin, K., Kay, A. C., \& Fitzsimons, G. J. (2012). Reactance versus rationalization: Divergent responses to policies that constrain freedom. Psychological Science, 23(2), 205-209. 